O.M. Lisova, S.M. Makhno, P.P. Gorbyk

\title{
EFFECT OF LOW-INTENSITY MICROWAVE ELECTROMAGNETIC RADIATION ON THE VITAL ACTIVITY OF YEAST IN THE PRESENCE OF GRAPHENE
}

\author{
Chuiko Institute of Surface Chemistry of National Academy of Sciences of Ukraine \\ 17 General Naumov Str., Kyiv, 03164,Ukraine,E-mail: oksana.garkusha@gmail.com
}

To study the influence of graphene (GN) and the low-intensity electromagnetic radiation (LEMP) in the range of $39.5-48.0 \mathrm{GHz}$ on the vital activity of the Saccharomyces cerevisiae yeast, an investigation of the rate of gassing power of yeast suspensions in the concentration of 0.03-0.12 wt. \% by means of a volumetric method is reported. Three independent series of experiments were performed: the first one included the dependence of gassing power rates of yeast suspensions on the GN concentrations; the second and third ones were done to research the rates of gassing power in the presence GN and at various LEMR frequencies, where the irradiation procedure was different. It has to be noted that the yeast aqueous suspensions (alone and in the combination with GN) were irradiated in the second series while the yeast in anabiotic state were irradiated afterward the substrate with GN was added in the third series. The respiration intensity of the yeast suspensions was assessed comparing with the blank during each experiment.

The vital processes of yeast suspensions are increased by 20-25\% compared to the blank in the presence of GN in the suspension, but no change of the gassing power rate behavior (as namely an acceleration or deceleration of lag phase, the change of the curve shape, etc.) in the presence of $G N$ was observed in some cases. The presence of GN in suspensions containing dry yeast is a motivating factor. The initial stage is more sensitive to the presence of GN in the suspension. The activity of the yeast at the final stage is more stable, almost linear and independent on the GN content in the GN concentration range. The value of the relative gassing power rate of the yeast suspensions containing GN is higher than that of blank experiment (about $30 \%$ ).

The mechanism of LEMR influence on microorganisms is under discussion for a long time, there is no common hypothesis concerning the reasons of this phenomenon, as the radiation wavelength significantly exceeds not only the size of the cell organelles, but also the size of the cell. Periodicity of the peaks in the case of yeast may indicate that the resonance phenomenon takes place not due to the actions of the first harmonics but as a result of its higher one. Namely, if the living organisms were exposure to the irradiation with monochromatic LEMR sources in the millimeter range, the resonance effect would not occur. It must be noted that the effect of resonance action can occur in the radio transparent atmosphere ( $\lambda=8-14,50-100$ microns) as radiation passes the waveguides filled with air and the filtration of the signal by the atmosphere components may occur.

Keywords: yeast, graphene, low-intensity electromagnetic radiation, the resonant effect

\section{INTRODUCTION}

The great attention of researchers has been attracted to the influence of graphene containing materials on the environment and human health $[1,2]$. Nowadays, there is no definite opinion about its effect on the living organisms where a negative influence of graphene nanocomposites on the environment is dominated. The study of the mechanisms of its action on the living systems is significant for the further development and safe use of graphene and its nanomaterials.

The investigation of graphene cytotoxicity included the graphene effect on the viability and morphology of cells, the integrity of membranes, the formation of reactive oxygen species, the damage of deoxyribonucleic acid, gene expression and others. The interaction of graphene nanoparticles depends on the physical, chemical and electrical properties, the surface charges, morphology (size, shape, sharp edges) and surface functionalization. The determining factors affected the reaction mechanism and the behavior of cells on graphene materials are the number of layers, the presence of crystalline and amorphous states, purity and synthesis methods, and others [2-4].

Adaptive effects arising under the lowintensity electromagnetic radiation (LEMR) are associated with plasmatic and intracellular membranes. Morphological and functional deviations of membranes are immediately revealed after exposure, even at low doses. The appeared changes can cause the proliferative processes, the acceleration of sodium cations transportation, the 
activation of peroxide oxidation of unsaturated fatty acids and the separation of the oxidation and phosphorylation processes in mitochondria [5]. It is known that the biological response of the cell to LEMR influence is selective, and the surface phenomena resulted in the interaction with the high dispersive particles and carbon-containing compounds play an important role in the living organisms processes. The experimental works connected with the simultaneous effect of LEMR and high dispersive particles on the vital processes of cells have essential interest.

The aim of this work is to study the changes in the vital processes of the Saccharomyces cerevisiae yeast in nutritional medium containing graphene nanoplates (GN) after prolonged exposure of cell to LEMR in the anabiotic state, as well as the influence of different frequencies of LEMR on yeast in suspension in the presence of GN.

\section{METHODS AND MATERIALS}

Graphenes were synthesized by the electrochemical dispergation of graphite electrodes in low concentrated alkaline electrolyte (potassium hydroxide) passing the current from 6.0 to $60.0 \mathrm{~mA} / \mathrm{cm}^{2}$. The electrodes were placed between the polypropylene filters to separate the large graphite particles from nanosized ones.

The dehydrated Saccharomyces cerevisiae yeast used in this investigation was obtained from «S.I.Lesaff» (France). The influence of GN (in the concentration range of $0.03-0.12$ wt. \%) and LEMR (in the frequency range of $39.5-48.0 \mathrm{GHz}$ ) on the activity of yeast in suspension was studied. Irradiation of LEMR was carried out by a generator G4-141 for $1 \mathrm{~h}$. The rate of gassing power of the yeast suspensions was controlled by a volumetric method. Three independent series of experiments were performed: the first one included the dependence of gassing power rates of yeast suspensions on the GN concentrations; the second and third ones were done to research the rates of gassing power in the presence of GN and at various LEMR frequencies, where the irradiation procedure was different. It has to be noted that the yeast aqueous suspensions (alone and in the combination with GN) were irradiated in the second series while the yeast in anabiotic state were irradiated afterward the substrate with GN was added in the third series [6]. The respiration intensity of the yeast suspensions was assessed comparing with the blank during each experiment.

\section{EXPERIMENTAL RESULTS AND DISCUSSION}

The dependence of the rate of gassing power on GN concentration (Fig. 1) is almost linear and hardly dependent on the GN content in the concentration range of $0.03-0.12 \%$. The vital processes of yeast suspensions are increased by 20-25\% compared to the blank in the presence of GN in the suspension, but the changes of the gassing power rate behavior (as namely an acceleration or deceleration of lag phase, the change of the curve shape, etc.) in the presence of GN were not observed in some cases. Thus, the presence of GN in yeast suspensions is a motivating factor and it does not cause the negative effects on vital processes at the cellular level.

The initial stage is more sensitive to the presence of GN in the suspension. The activity of the yeast at the final stage is more stable, almost linear and independent on the GN content in the GN concentration range (Fig. 1, curve 2). The value of the relative gassing power rate of the yeast suspensions containing GN is higher than that of blank experiment (about $30 \%$ ).

The dependence of relative gassing power rate of yeast suspensions irradiated in the anabiotic state at $46.5 \mathrm{GHz}$ frequency (curve 2) and non-irradiated ones (curve 3) on GN concentrations is shown in Fig. 2. The result presented in curve 1 is independent on the concentration, it represents experimental values obtained in a single experiment, and curve 2 shows those for yeast irradiated at the frequency of $46.5 \mathrm{GHz}$. As shown in Fig. 2, the negative effect of LEMR on the activity of yeast suspensions (curve 1) is compensated by the presence of GN (curve 3) to the level of activity of non-irradiated yeast. The low GN concentrations have more significant effect, although the experimental data are changed at the level of errors.

The values of relative gassing power rate (Fig. 3) are disordered, where the deviation on the average value is within the experimental error and can be averaged for the aqueous suspension (curve 1) and the suspension with GN (curve 2). The influence of frequency (curve 1) is not pronounced due to significant absorption of electromagnetic energy by water [7]. The intensity of the suspension with GN (curve 2) is higher indicating a general trend of yeast suspensions to activate the vital processes in the presence of GN. 


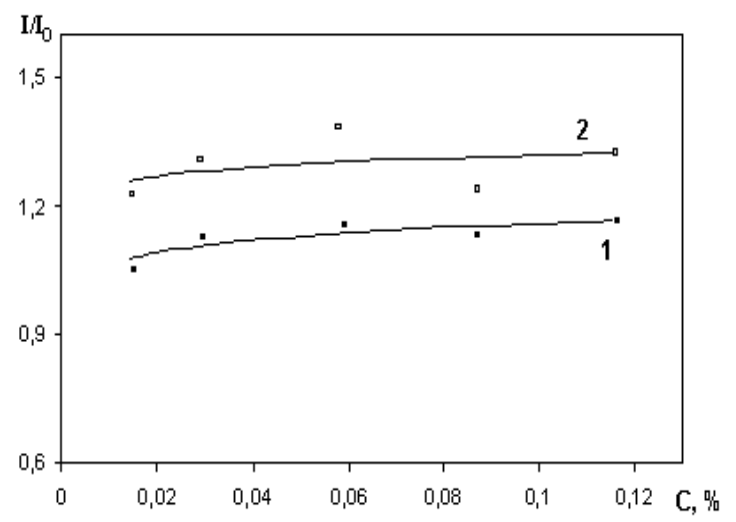

Fig. 1. Dependence of the relative gassing power rate of yeast suspensions on GN concentrations: 1 the initial and 2 - final stages of suspension

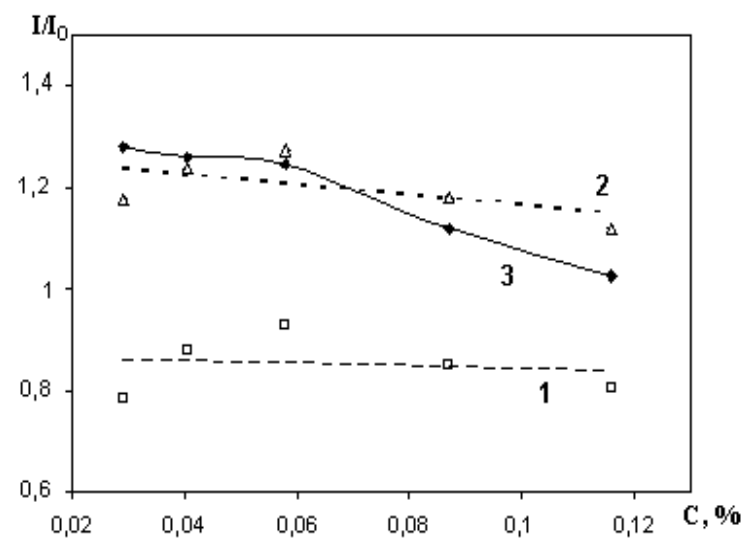

Fig. 2. Dependence of the relative gassing power rate of yeast suspensions on GN concentrations: 1 irradiation without GN; 2 - without irradiation; 3 - irradiation with different GN content

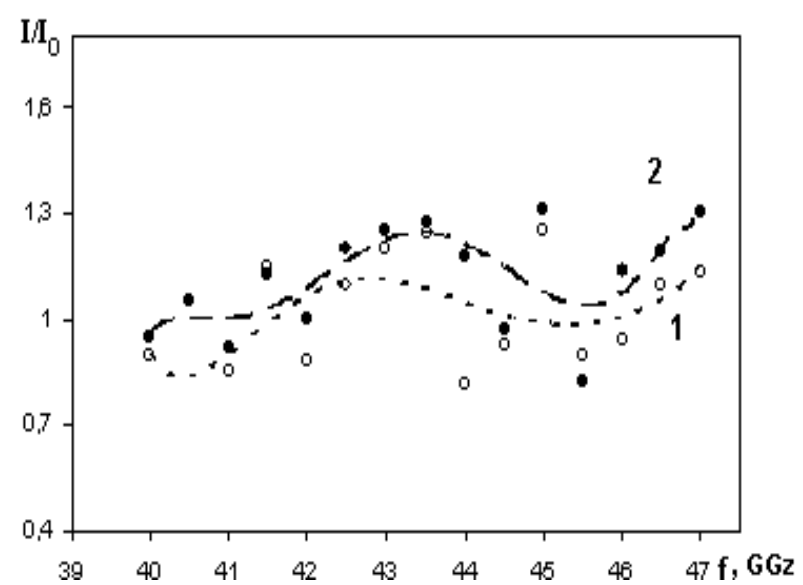

Fig. 3. The dependence of relative gassing power rate of irradiated yeast suspensions on LEMR frequency 1 - the aqueous suspension; 2 - the suspension with GN (0.12 \%)
The dependence of relative gassing power rate of irradiated yeast in dehydrated state (curve 1) and in the presence of GN suspension (curve 2) on the radiation frequency displays the narrow peaks of activity that are separated by broad frequency range corresponded to the inhibition of the vital processes (Fig. 4). General view of curve 1 is correlated with the previously obtained results [6] for the reported frequency range. The increase in the activity of vital processes of yeast suspensions containing GN (curve 2) by 20-25\% compared to the blank occurs, but the changes of gassing power rate behavior with time are not observed. The presence of GN in suspensions containing dry yeast is a motivating factor.

The mechanism of LEMR influence on microorganisms is under discussion for a long time, there is no common hypothesis concerning the reasons of this phenomenon, as the radiation wavelength significantly exceeds not only the size of the cell organelles, but also the size of the cell. Periodicity of the peaks [6] in the case of yeast (Fig. 4) may indicate that the resonance phenomenon takes place not due to the actions of the first harmonics but as a result of its higher one. Namely, if the living organisms were exposure to the irradiation with monochromatic LEMR sources in the millimeter range, the resonance effect would not occur. It must be noted that the effect of resonance action could occur in the radio transparent atmosphere ( $\lambda=8-14,50-100$ microns) as radiation passes the waveguides filled with air and the filtration of the signal by the atmosphere components may occur.

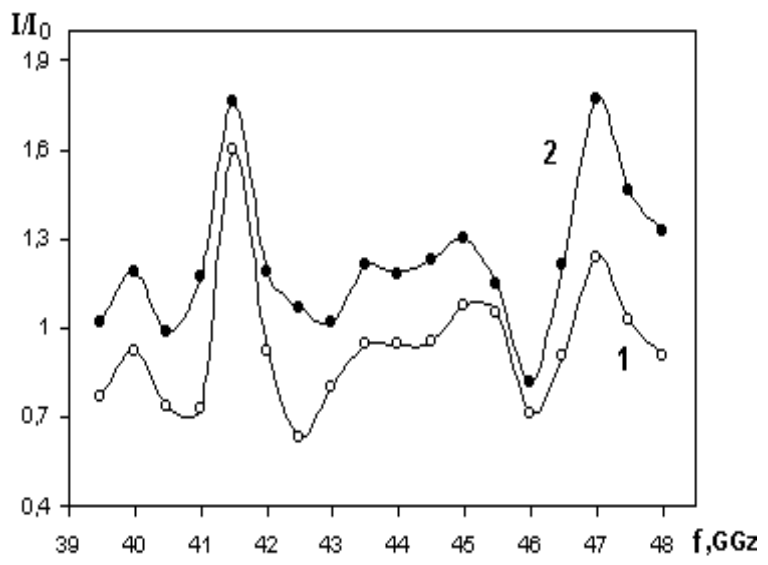

Fig. 4. The dependence of relative gassing power rate of yeast suspensions irradiated under anabiotic conditions: 1 - without GN; 2 - with GN (0.12\%) suspension on LEMR frequency 


\section{CONCLUSIONS}

The increased activity of the yeast vital processes by $\sim 30 \%$ is observed in the presence of GN (0.03-0.12 wt. \%) in suspension while it does not depend on the concentration of GN in the nutrient substrate. The intensity of gassing power of the yeast suspensions irradiated in the hydrated state (and also in the presence of GN) is not correlated with the frequency opposite to the ones irradiated in the anabiotic condition. It is explained by significant absorption of electromagnetic energy in the frequency range reported above by water.

The relative gassing power rate of irradiated dry yeast has a resonant character: the narrow peaks of activity are split by the wide frequency range where the vital processes are inhibited. Filling the suspension containing the irradiated yeast with GN is a stimulating acidity factor (20-25\%) and does not cause the negative effects on the vital processes at the cellular level.

\title{
Вплив мікрохвильового низькоінтенсивного електромагнітного випромінювання на життєдіяльність клітин дріжджів у присутності графенів
}

\author{
О.М. Лісова, С.М. Махно, П.П. Горбик
}

Інститут хімії поверхні ім. О.О. Чуйка Національної академії наук України вул. Генерала Наумова, 17, Київ, 03164, Україна, oksana.garkusha@gmail.com

\begin{abstract}
3 метою виявлення впливу графенів та низькоінтенсивного електромагнітного випромінювання частотного діапазону 39.5-48ГГи на життєдіяльність дріжджів Saccharomyсеs cerevisiae проведено дослідження швидкості газовиділення суспензій дріжджів в інтервалі концентрацій 0.03-0.12 мас.\% волюметричним методом.

При введенні в суспензї дріжджів графенів відбувалась активізачія прочесів життєдіяльності до 30 \%. Для дріжджів, які опромінювались в суспензї (з графенами також) кореляиії інтенсивності газовиділення 3 частотою не спостерігається, щуо обумовлено значним поглинанням електромагнітної енергії водою. Залежність відносної швидкості газовиділення опромінених в сухому стані клітин дріжджів має резонансний характер: вузькі піки активності розділено широким інтервалом частот, на якому процеси життєдіяльності пригнічуються. Введення графенів в суспензію з опроміненими клітинами дріжджів стимулює процеси життєдіяльності і не спричиняє негативного впливу на клітинному рівні.
\end{abstract} ефект

Ключові слова: дріжджі, графени, низькоінтенсивне електромагнітне випромінювання, резонансний

\section{Влияние микроволнового низкоинтенсивного электромагнитного излучения на жизнедеятельность клеток дрожей в присутствии графенов}

\author{
О.М. Лисова, С.Н. Махно, П.П. Горбик
}

Институт химии поверхности им. А.А. Чуйко Наџиональной академии наук Украинь ул. Генерала Наумова, 17, Киев, 03164, Украина, oksana.garkusha@gmail.com

С иелью выявления влияния графенов и низкоинтенсивного электромагнитного излучения частотного диапазона 39.5-48ГГи на жизнедеятельность дрожжей Saccharomyсеs cerevisiae проведено исследование скорости газовыделения суспензий дрожжей в интервале концентраций 0.03-0.12 масс. \% волюметрическим методом.

При введении в суспензии дрожжей наночастии графена происходит активизаџия процессов жизнедеятельности до 30 \%. Для дрожжей, которые облучались в суспензии (с графенами тоже) корреляции 
интенсивности газовыделения с частотой не наблюдается, что обусловлено значительным поглощением электромагнитной энергии водой. Зависимость относительной скорости газовылеления облученньх в сухом состоянии клеток дрожжей имеет резонансный характер: узкие пики активности разделены широким интервалом частот, на котором процессы жизнедеятельности подавляются. Введение графенов в суспензию с облученных клеток дрожжей стимулирует процессы жизнедеятельности и не оказывает отрицательного влияния на клеточном уровне.

Ключевые слова: дрожжи, графены, низкоинтенсивное электромагнитное излучение, резонансный эффект

\section{REFERENCES}

1. Gao H., Zhou R. Cytotoxicity of graphene: recent advances and future perspective. Nanomed. Nanobiotechnol. 2014. 6(5):452.

2. Grace A., Chandra E.S., Malai A., Ponmari A., Vani G., Rose G., Marahatta A., Babu A., Gunasekaran V. Cytotoxicity and antibacterial characteristics of graphene-oxide nanosheets toward human pathogens. J. Nanosci. Nanotechnol. 2016. 16(3): 2447.

3. Hu Y., Li F., Han D., Niu L. Biocompatible Graphene for Bioanalytical Applications. (SpringerBriefs in Molecular Science, 2015).

4. Jarosz A., Skoda M., Dudek I., Szukiewicz D. Oxidative stress and mitochondrial activation as the main mechanisms underlying graphene toxicity against human cancer cells oxidative. Medicine and Cellular Longevity. 2016. 2016: 14.

5. Vyzulina V.I. Ph.D (Phys.-math.) Thesis. (Krasnodar, 2008). [in Russian].

6. Gorbyk P.P., Mazurenko R.V., Makhno S.N., Garkusha O.M., Bagatskaya A.N. Influence of superfine oxides and low-intensity electromagnetic radiation on the activity of biological systems. Nanomaterials and nanocomposites in medicine, biology, ecology. (Kiev: Naukova Dumka, 2011). [in Russian].

7. Harvey A.F. Microwave Engineering. (London and NY: Academic Press, Royal Radar Esteblishment, 1963). 